\title{
POLA BAKTERI AEROB PENYEBAB KONJUNGTIVITIS PADA PENDERITA RAWAT JALAN DI BALAI KESEHATAN MATA MASYARAKAT KOTA MANADO
}

\author{
${ }^{1}$ Manly Lolowang \\ 'John Porotu'o \\ ${ }^{3}$ Fredine Rares
}

\author{
${ }^{1}$ Kandidat Skripsi Fakultas Kedokteran Universitas Sam Ratulangi Manado \\ ${ }^{2,3}$ Bagian Mikrobiologi Fakultas Kedokteran Universitas Sam Ratulangi Manado \\ Email : manly.lolowang10_121@yahoo.co.id
}

\begin{abstract}
Abstrak : Konjungtivitis merupakan peradangan pada konjungtiva. Insidensi di Indonesia mencapai 73\% dari total kunjungan di poli mata pada tahun 2009. Salah satu penyebab konjungtivitis adalah infeksi bakteri. Di Manado belum ada data mengenai pola bakteri penyebab konjungtivitis sehingga dapat menyebabkan kesalahan dalam pemilihan antimikroba bagi pasien.Tujuan dari penelitian ini adalah unutk mengetahui pola bakteri aerob pada penderita konjungtivitis yang dapat berkontribusi langsung dalam peningkatan kualitas penanganan konjungtivitis, terutama konjungtivitis bakterial.Penelitian ini menggunakan metode penelitian deskriptif dengan pendekatan cross sectional melalui penelitian kultur bakteri hasil swab konjungtiva penderita konjungtivitis di Balai Kesehatan Mata Masyarakat Kota Manado. Sampel dalam penelitian ini adalah pasien dengan diagnosis konjungtivitis bakterial dengan infeksi yang masih berlanjut dan belum menjalani pengobatan dengan antimikroba. Distribusi sampel penelitian berdasarkan jenis kelamin didapatkan hasil 12 orang (40\%) pria dan 18 orang (60\%) wanita. Umur termuda dalam penelitian ini 26 tahun dan tertua 77 tahun. Hasil penelitian menunjukan 7 sampel tidak ada pertumbuhan pada proses kultur, 12 sampel terdapat bakteri gram positif, 1 sampel bakteri gram negatif dan 10 sampel campuran bakteri gram positif dan negatif. Streptococcus non hemolitikus ditemukan pada 11 sampel (36,67\%), Bacillus subtilis pada 7 sampel (23,33\%), Proteus spp pada 6 sampel (20\%), Staphylococcus albus pada 5 sampel (16,67\%), Diplococcus gram negatif pada 4 sampel (13,33\%), Lactobacillus spp pada 3 sampel (10\%) dan Pseudomonas aeuruginosa 1 sampel (3,33\%). Kesimpulan pada penelitian ini terbanyak infeksi pada konjungtivitis disebabkan Streptococcus non hemolitikus dan tersering pada kelompok umur diatas 60 tahun.

Kata kunci : konjungtivitis, bakteri aerob, pola bakteri
\end{abstract}

Abstract : Conjunctivitis is an inflammation of the conjungtiva. Incidence in Indonesia reached 73\% of total visits in ophthalmlogy polyclinic in 2009. One cause of conjunctivitis is bacterial infection. In Manado, no data on the pattern of the bacteria that cause conjunctivitis that can cause errors in the selection of antimicrobials for patient.The aim this research is to assess the pattern of aerobic bacteria in patients with conjunctivitis which can contribute directly in improving the quality of treatment of conjunctivitis, especially bacterial conjunctivitis. This research use methods with cross sectional descriptive study through a conjunctival swab bacterial culture results in patients with conjunctivitis at Community Eye Health Center in Manado. The samples in this study were patients with a diagnosis of bacterial conjunctivitis with ongoing infection and has not undergone treatment with antimicrobials. Distribution of the study sample by sex showed 12 people (40\%) men and 18 (60\%) women. The youngest age in this study 26 years old and the oldest 77 years old. 7 sample results showed no growth on 
culture process, 12 samples contained gram-positive bacteria, 1 sample gram-negative bacteria and 10 samples of a mixture of gram positive and negative bacteria. Non-haemolytic Streptococcus was found in 11 samples (36.67\%), Bacillus subtilis on 7 samples (23.33\%), Proteus spp in 6 samples (20\%), Staphylococcus albus in 5 samples (16.67\%), Diplococcus grams negative in 4 samples (13.33\%), Lactobacillus spp in 3 samples (10\%) and Pseudomonas aeuruginosa 1 sample (3.33\%). The conclusion of this research on the most infectious conjunctivitis caused by non-haemolytic Streptococcus and most common in the age group above 60 years. Keywords: conjunctivitis, aerobic bacteria

Konjungtivitis merupakan peradangan pada konjungtiva. ${ }^{1} \quad$ Konjungtivitis merupakan penyakit mata tersering yang menyebabkan keluhan mata merah. Satu dari delapan siswa sekolah dasar memiliki sebuah episode konjungtivitis setiap tahunnya dan secara umum pada praktek dokter umum menemukan pasien konjungtivitis setiap minggunya. ${ }^{2}$

Di Negara maju seperti Amerika, insidensi konjungitivitis bakteri mencapai 135 per 10.000 penderita. $^{3}$ Sementara itu di Indonesia pada tahun 2009 dari 135.749 kunjungan ke poli mata, total kasus konjungtivitis dan gangguan lain pada konjungtiva didapatkan hasil sebesar 73\%. Konjungtivitis juga termasuk dalam 10 besar penyakit terbesar yang dialami pasien rawat jalan pada tahun 2009. ${ }^{4}$

Pada penelitian yang dilakukan di Nepal pada Januari 2009 sampai dengan Desember 2010, dari 65 pasien dengan keluhan mata merah dan adanya sekret didapatkan hasil 90,8\% sampel tidak menunjukan adanya pertumbuhan bakteri pada proses kultur, sementara itu 7,7 \% sampel menunjukan pertumbuhan bakteri gram positif, sisanya menunjukan pertumbuhan gram negatif. ${ }^{5}$ Hal ini bertolak belakang dengan hasil yang didapatkan pada penelitian di Nigeria pada bulan Februari sampai dengan September 2010. Pada penelitian di Nigeria, dari 83 sampel yang diambil didapatkan 100\% pertumbuhan bakteri pada kultur yang dilakukan dengan total 155 bakteri terisolasi dari sampel tersebut. ${ }^{6}$ Sementara itu, pada penelitian yang dilakukan di RSUP Dr. Kariadi Semarang pada tahun 2010, didapatkan 35\% pasien konjungtivitis mengalami konjungtivitis bakterial dan perlu diberikan antibiotik. $^{7}$

Secara umum penyebab tersering konjungtivitis bakterial adalah mikroorganisme gram positif yaitu: Staphylococcus aureus, Streptococcus pneumonia, Streptococcus viridians, dan Staphylococcus epidermidis. Konjungtivitis dapat juga disebabkan oleh mikroorganisme gram negatif, diantaranya Escherichia coli, Klebsiella pneumonia, Serratia marcescens, Proteus, Enterobacter, dan Pseudomonas species. ${ }^{2,8}$ Pada anak-anak penyebab tersering adalah Haemophilus influenza, Streptococcus pneumonia, dan Moraxella species. ${ }^{9}$

Berdasarkan hasil survey pendahuluan yang dilakukan di Balai Kesehatan Mata Masyarakat Kota Manado pada tahun 2012 ditemukan 356 pasien konjungtivitis diantara 13.189 pasien yang datang untuk mendapatkan pelayanan kesehatan dan merupakan salah satu dari 5 penyakit tersering yang dialami pasien di Balai Kesehatan Mata Masyarakat Kota Manado. Selain itu berdasarkan data tersebut, konjungtivitis juga menduduki peringkat pertama penyakit infeksi tersering yang 
dialami pasien yang datang berobat. Sementara itu untuk data pola kuman pada infeksi konjungtivitis tidak didapatkan baik untuk Kota Manado maupun untuk Provinsi Sulawesi Utara.Hal ini dapat mengakibatkan ketidaktahuan klinisi mengenai penggunaan antibiotik yang tepat berdasarkan pola bakteri penyebab konjungtivitis yang dapat mengakibatkan timbulnya resistensi antibiotik. Dari latar belakang diatas, maka perlu dilakukan penelitian tentang pola bakteri aerob pada penderita konjungtivitis di Balai Kesehatan Mata Masyarakat Kota Manado.

\section{METODE PENELITIAN}

Penelitian ini dilakukan dengan metode deskriptif dengan pendekatan cross sectional melalui penelitian kultur hasil swab konjungtiva penderita konjungtivitis sebanyak 30 sampel di Balai Kesehatan Mata Masyarakat Kota Manado periode November 2013 sampai dengan Januari 2014. Pengambilan sampel di Balai Kesehatan Mata Masyarakat Kota Manado dan Pengelolaan sampel dilakukan di Laboratorium Mikrobiologi Fakultas Kedokteran Unsrat.

Swab steril digunakan untuk mengambil spesimen konjungtiva pada penderita. Swab disapukan secara lembut di daerah konjungtiva dari medial ke lateral mata pasien setelah sebelumnya penderita diberi $1-2$ tetes pantocain 0,5\%. Kemudian spesimen konjungtiva diinokulasikan di media nutrien agar. Setelah itu dipindahkan ke media agar mac conkey dan media agar darah. Kemudian diinkubasikan pada suhu $37^{\circ} \mathrm{C}$ selama 24 jam.Setelah tumbuh koloni , dilakukan pewarnaan gram kemudian dilanjutkan dengan uji biokimia. Kemudian dilakukan identifikasi.

\section{HASIL PENELITIAN}

\section{Distribusi Sampel}

Penderita rawat jalan di BKMM Kota Manado yang memeriksakan diri dan terdiagnosa secara klinis menderita konjungtivitis bakterial dilakukan pengambilan spesimen mata sebanyak 30 sampel. Distribusi sampel berdasarkan jenis kelamin didapatkan hasil 12 orang (40\%) berjenis kelamin Pria, sedangkan 18 orang (60\%) berjenis kelamin Wanita. Sementara itu, menurut kelompok umur didapatkan hasil pada kelompok umur 1 bulan sampai dengan 10 tahun dan 11 - 20 tahun tidak didapatkan sampel (0). kelompok umur 2130 tahun sebesar 1 sampel (3,3\%), 31-40 tahun sebesar 4 sampel (13,3\%), 41-50 tahun sebesar 9 sampel (30\%), 51-60 tahun sebesar 6 sampel (20\%) dan diatas 60 tahun sebesar 10 sampel $(33,4 \%)$.

\section{Hasil Biakan}

Pemeriksaan sampel hasil swabbing spesimen konjungtiva di Balai Kesehatan Mata Masyarakat Kota Manado yang dilakukan di Laboratorium Mikrobiologi Fakultas Kedokteran Unsrat menunjukan hasil yang ditunjukan melalui tabel 1 dan 2 .

Tabel 1 Distribusi Sampel Berdasarkan Pertumbuhan Kultur Kuman di media Nutrien Agar dan Mac Conkey

\begin{tabular}{|l|l|l|}
\hline Hasil Kultur & $\begin{array}{l}\text { Jumlah } \\
\text { Sampel }\end{array}$ & $\begin{array}{l}\text { Presentase } \\
(\%)\end{array}$ \\
\hline Ada Pertumbuhan & 23 & 76,7 \\
\hline $\begin{array}{l}\text { Tidak ada } \\
\text { Pertumbuhan }\end{array}$ & 7 & 23,3 \\
\hline Total & 30 & 100 \\
\hline
\end{tabular}

Tabel 1 tampak bahwa distribusi sampel berdasarkan pertumbuhan kultur kuman didapatkan hasil sampel yang menunjukan adanya pertumbuhan sebesar 23 
sampel $(76,7 \%)$ dan yang tidak menunjukan adanya pertumbuhan sebesar 7 sampel $(23,3 \%)$.

Tabel 2 Distribusi Sampel Berdasarkan Hasil Pewarnaan Gram dan identifikasi secara

mikroskopis

\begin{tabular}{|l|c|}
\hline Jenis Bakteri & Jumlah sampel \\
\hline Bakteri gram positif & 12 \\
Bakteri gram negatif & 1 \\
Infeksi Campuran & 10 \\
\hline
\end{tabular}

Tabel 2 menunjukan distribusi sampel berdasarkan hasil pewarnaan gram dan identifikasi secara mikroskopis, pada 12 sampel ditemukan adanya infeksi oleh bakteri gram positif, pada 1 sampel bakteri gram positif dan 10 sampel ditemukan adanya infeksi campuran oleh bakteri gram positif dan bakteri gram negatif.

Tabel 3 Hasil Biakan Kuman dari spesimen konjungtiva penderita konjungtivitis di BKMM Kota Manado

\begin{tabular}{lc}
\hline \multicolumn{1}{c}{ Bakteri } & Jumlah (\%) \\
\hline $\begin{array}{l}\text { Streptococcus non } \\
\text { hemolitikus }\end{array}$ & $11(36,67)$ \\
& $(23,33)$ \\
& $(20,00)$ \\
Bacillus subtilis & $6(16,67)$ \\
Proteus spp & $4(13,33)$ \\
Staphylococcus albus & $3(10,00)$ \\
Diplococcus gram negatif & \\
Lactobacillus spp & $1(3,33)$ \\
Pseudomonas aeuruginosa & \\
\hline
\end{tabular}

Tabel 3 menunjukan hasil biakan kuman dari spesimen konjungtiva penderita konjungtivitis di BKMM Kota Manado berdasarkan hasil kultur di media nutrien agar, mac conkey dan agar darah, hasil identifikasi secara mikroskopis dan hasil uji biokimia, dimana bakteri Streptococcus non hemolitikus ditemukan pada 11 sampel (36,67 \%) , Bacillus subtilis sebesar 7 sampel (23,33\%), Proteus spp sebesar 6 sampel (20,00\%), Staphylococcus albus sebesar 5 sampel (16,67 \%) , bakteri diplococcus gram negatif sebesar 4 sampel (13,33 \%), bakteri Lactobacillus sebesar 3 sampel (10,00\%) dan bakteri Pseudomonas aeuruginosa sebesar 1 sampel (3,33\%)

\section{BAHASAN}

Distribusi sampel berdasarkan jenis kelamin didapatkan hasil 12 orang (40\%) berjenis kelamin Pria, sedangkan 18 orang (60\%) berjenis kelamin Wanita. Angka ini sama dengan yang didapatkan dari penelitian yang dilakukan di Universitas Kathmandu, Nepal. ${ }^{5}$ Dimana penelitian di Nepal menggunakan metode pengambilan sampel yang sama dengan penelitian ini, yaitu secara acak berdasarkan periode waktu tertentu. Penelitian yang dilakukan di Medan juga tidak menunjukan adanya perbedaan yang signifikan proporsi jenis kelamin penderita konjungtivitis. ${ }^{10}$ Jika ada perbedaan, hal ini berkaitan dengan lifestyle, kondisi hygiene dan lingkungan pekerjaan. ${ }^{10}$

Distribusi sampel pada penelitian ini usia termuda adalah 26 tahun dan tertua adalah 77 tahun. Berdasarkan kelompok umur didapatkan hasil pada kelompok umur 1 bulan sampai dengan 10 tahun dan umur 11 - 20 tahun tidak didapatkan sampel. Sementara itu pada kelompok umur 21- 30 tahun sebesar 1 sampel (3,3\%), 31-40 tahun sebesar 4 sampel (13,3\%), 41-50 tahun sebesar 9 sampel (30\%), 51-60 tahun sebesar 6 sampel (20\%) dan diatas 60 tahun sebesar 10 sampel (33,4\%). Hal ini sesuai dengan data insidensi di negara Amerika Serikat tahun 2003 bahwa konjungtivitis 
bakterial lebih sering terjadi pada kelompok umur dewasa. ${ }^{3}$ Hal ini sesuai juga dengan penelitian yang dilakukan di Medan, dimana didapatkan hasil konjungtivitis cenderung lebih sering ditemukan pada orang dewasa. ${ }^{10}$

Pada penelitan ini juga ditemukan bahwa pada usia dewasa, kelompok yang tersering adalah kelompok usia diatas 60 tahun atau yang lebih dikenal dengan kelompok geriatri. Ada beberapa faktor yang dapat menyebabkan kelompok geriatri lebih beresiko untuk menderita konjungtivitis, diantaranya pada kelompok usia lanjut juga terjadi pengurangan lakrimasi yang pada akhirnya dapat mengakibatkan peningkatan risiko infeksi pada mata dan berkurangnya proteksi humoral yang berasal dari immunoglobulin di mata. ${ }^{11-13}$ Selain itu, pengurangan lakrimasi pada usia lanjut juga mengakibatkan adanya perubahan pada mukosa mata, perubahan ini mengakibatkan adanya perubahan flora normal pada mata yang juga mengurangi proteksi mata terhadap bakteri-bakteri patogen. ${ }^{11}$ Pada kelompok geriatri dapat juga terjadi penurunan imunitas selular, penurunan produksi sel $\mathrm{T}$ dan sintesis sitokin menurun yang mengakibatkan kelompok usia ini lebih rentan terhadap infeksi. ${ }^{13}$ Penyakit-penyakit degeneratif lainnya yang diderita oleh kelompok lanjut usia dapat mengakibatkan tejadi penurunan daya tahan tubuh dan mengakibatkan peningkatan risiko terjadinya infeksi termasuk konjungtivitis. $^{13,14}$

Pada penelitian ini didapatkan hasil sebanyak 23 sampel menunjukan adanya pertumbuhan koloni bakteri pada kultur di media nutrien agar dan agar mac conkey, sedangkan 7 sampel tidak menunjukan adanya pertumbuhan. Hal ini dapat disebabkan oleh pasien menderita jenis konjungtivis yang lain seperti konjungtivitis viral maupun fungal. Namun tidak menutup kemungkinan pasien menderita konjungtivitis bakterial tetapi bakteri penyebabnya merupakan kuman anaerob yang dalam penelitian ini tidak dilakukan pemeriksaan lebih lanjut.

Hasil koloni bakteri yang tumbuh selanjutnya dilakukan pewarnaan gram dan selanjutnya dilakukan identifikasi dengan pemeriksaan secara mikroskopis. Berdasarkan tabel 2 didapatkan hasil pada 12 sampel ditemukan adanya infeksi oleh bakteri gram positif, pada 1 sampel bakteri gram negatif dan 10 sampel ditemukan adanya infeksi campuran oleh bakteri gram positif dan bakteri gram negatif. Hal ini sesuai dengan penelitian yang dilakukan di India, dimana ditemukan bakteri penyebab infeksi mata lebih sering karena bakteri gram positif. $^{15}$ Hal ini juga didukung oleh literatur yang mengemukakan bakteri gram positf seperti golongan Streptococcus spp dan Stafilococcus spp lebih sering ditemukan pada spesimen konjungtiva penderita konjungtivitis bakterial. ${ }^{11,14}$ Selanjutnya dilakukan uji biokimia yaitu uji motility, uji produksi $\mathrm{H}_{2} \mathrm{~S}$ dan uji pertumbuhan sitrat dan dianalisa

Berdasarkan tabel 3 didapatkan kuman tersering yang didapatkan pada penelitian ini adalah Streptococcus non hemolitikus sebanyak 11 sampel . Kuman Streptococcus spp merupakan salah satu flora normal pada konjungtiva. ${ }^{11,14,16}$ Sesuai dengan penelitian yang dilakukan di India pada tahun 2005, Streptococcus spp merupakan salah satu kuman penyebab infeksi mata termasuk konjungtivitis. $^{15}$ Penelitian tersebut juga mengemukakan kelompok kuman Streptococcus non hemolitikus seperti Streptococcus viridans sering ditemukan sebagai penyebab konjungtivitis selain kuman Streptococcus $\alpha$ hemolitikus ${ }^{15}$ Hal ini sama dengan penelitian yang dilakukan di Ethiopia tahun 2004. ${ }^{16}$

Selanjutnya kuman yang ditemukan dalam penelitian ini adalah Bacillus subtilis yang juga merupakan salah satu kuman yang dapat ditemukan sebagai flora normal di 
konjungtiva. ${ }^{11}$ Hal ini sesuai dengan penelitian yang dilakukan di Ethiopia dimana didapatkan hasil pertumbuhan Bacillus subtilis mencakup 5\% dari kuman yang tumbuh dan di Nigeria yang mencakup 6,5\% dari kuman yang tumbuh. ${ }^{6,16}$ Selain itu pada penelitian di India dan Amerika juga menemukan Bacillus subtilis sebagai salah satu bakteri yang terisolasi dari hasil kultur spesimen konjungtiva penderita konjungtivitis. ${ }^{15,17}$

Proteus spp ditemukan sebesar 6 sampel (20\%) dalam penelitian ini. Proteus spp merupakan salah satu penyebab konjungtivitis yang onsetnya dapat berlangsung kronik. ${ }^{14}$ Proteus spp termasuk salah satu penyebab konjungtivitis yang sering ditemukan di berbagai penelitian, seperti penelitian di Selandia Baru, Portugal , India dan Amerika Serikat. ${ }^{15,17,18}$

Selain itu pada penelitian ini ditemukan juga kuman Staphylococcus albus. Staphylococcus albus juga dikenal sebagai Staphlocococcus epidermidis yang berfungsi sebagai flora normal pada kulit dan mata manusia. ${ }^{11,19}$ Hasil ini sesuai dengan penelitian yang dilakukan di Nigeria, dimana didapatkan hasil Staphylococcus albus merupakan salah satu bakteri gram positif yang cukup dominan menyebabkan infeksi konjungtiva disamping Staphylococcus aureus. ${ }^{6}$ Penelitian lainnya di Amerika dan India juga menemukan Staphylococcus epidermidis dalam hasil kultur yang dilakukan. ${ }^{15,16}$ Kuman golongan Staphylococcus merupakan kuman tersering penyebab konjungtivitis pada orang dewasa yang dapat menyebabkan infeksi secara akut maupun kronik . ${ }^{11,12,14,20}$

Kuman lainnya yang ditemukan dalam penelitian ini adalah kuman Diplococcus gram negatif dan Pseudomonas aeuruginosa. Diplococcus gram negatif didapatkan sebanyak 4 sampel sedangkan Pseudomonas aeuruginosa hanya ditemukan di 1 sampel. Kelompok kuman Diplococcus gram negatif yang dapat menyebabkan konjungtivitis antara lain Neisseria spp dan Moraxella spp dan dapat menyebabkan konjungtivitis dengan sekret yang purulen maupun konjungtivitis subakut. ${ }^{16,19}$ Penelitian-penelitian di India, Amerika Serikat dan Selandia Baru juga menemukan adanya kuman-kuman ini dalam jumlah yang sedikit dari hasil kultur yang dilakukan. ${ }^{15,17,21}$

Dalam penelitian ini juga ditemukan Lactobacillus spp sebanyak 3 sampel. Lactobacillus spp merupakan flora normal di usus dan ditemukan juga pada bayi atau mereka yang banyak mengkonsumsi laktosa. ${ }^{19,22}$ Sampai saat ini belum ada literatur yang menjelaskan adanya hubungan antara Lactobacillus spp dan konjungtivitis. Pada penelitian ini Lactobacillus spp dicurigai merupakan kuman hasil kontaminasi selama penelitian dilakukan.

\section{SIMPULAN}

Berdasarkan penelitian yang dilakukan dapat ditarik simpulan bahwa bakteri aerob terbanyak penyebab konjungtivitis di Balai Kesehatan Mata Masyarakat yang tersering adalah bakteri gram positif, yaitu bakteri Streptococcus non hemolitikus. Selain itu, sampel pada penelitian ini lebih sering pada wanita dan kelompok umur diatas 60 tahun.

\section{DAFTAR PUSTAKA}

1. Ilyas HS, Ilmu Penyakit Mata.Edisi ke-3. Jakarta: FKUI 2010. h. 120-145

2. Oliver GF, Wilson GA, Everts RJ. Acute infective conjunctivitis: evidence review and management advice for New Zealand practitioners. The New Zealand Medical Journal. 2009;122:69-75 diakses tanggal 23 sep 2013 melalui http://www.nzma.org.nz/journal/122$\underline{1298 / 3688 /}$ 
3. Smith AF, Waycaster C. Estimate of the direct and indirect annual cost of bacterial conjunctivitis in the United States. Biomed Central. 2009;1-11 diakses tanggal 25 sep 2013 melalui http://www.biomedcentral.com/14712415/9/13

4. Kemenkes RI, 2010. 10 Besar Penyakit Rawat Jalan Tahun 2009. Profil Kesehatan Indonesia tahun 2009 diakses tanggal 23 sep 2013 melalui http://www.depkes.go.id

5. Staphit PR, Tuladhar NR, Marasini S, Khoju U, Thapa G. Bacterial conjunctivitis and use of antibiotics in dhulikhel hospital-kathmandu university hospital. Kathmandu University Medical Journal.2011;34:69-72 diakses tanggal 25 sep 2013 melalui http://www.nepjol.info/index.php/KUMJ /article/view/6292

6. Iwalokun BA, Oluwadun A, Akinsinde KA, Niemogha MT, Nwaokorie FO. Bacteriologic and plasmid analysis of etiologic agents of conjunctivitis in Lagos, Nigeria. Journal of Ophtalmic Inflammation and Infection . 2011;1:95103 diakses tanggal 25 september 2013 melalui

http://link.springer.com/article/10.1007/s 12348-011-0024-z

7. Tampi GG, Nugroho T. Rasionalitas penggunaan antibiotika dalam penatalaksanaan konjungtivitis di bagian mata RSUP DR. Kariadi semarang. 2010 diakses tanggal 22 sep 2013 melalui http://eprints.undip.ac.id/33301/

8. Afjeiee SA, Tabatabaei SR, Fallah F, Shiva F, Zanjani NT, Fard AT et al. A microbiological study of neonatal conjunctivitis in two hospitals in Teheran Iran. Asian Pasific Journal of Tropical Disease.2013;3(6): 429-433 diakses tanggal 25 sep 2013 melalui http://bjo.bmj.com/content/61/9/601.shor $\underline{t}$
9. Tarabishy AB, Jeng BH. Bacterial conjunctivitis: A revies for internist. Cleveland Clinic Journal of Medicine. 2008;75:507-512 diakses tanggal 25 sep 2013 melalui http://ccjm.org/content/75/7/507.short

10. Hutagalung PY, Hiswani, Jemadi. Karakteristik penderita konjungtivitis rawat jalan di rsud dr. pirngadi Medan.2011 diakses tanggal 24 september 2013 melalui http://jurnal.usu.ac.id/index.php/gkre/arti cle/view/1187

11. Skuta GI, Cantor LB, Weiss IS. Infectious diseases of the external eye : basic concepts, infectious diseases of the external eye : clinical aspect, degenerative and aging processes in External Disease and Cornea. Edisi 8. United States: American Academy of Ophtalmology : 2008-2009

12. Khurana AK, Comprehensive Ophtalmology edisi ke 4. New Delhi: New Age International; 2007

13. Rahayu RA, Bahar A. Penatalaksanaan Infeksi Pada Usia Lanjut Secara Menyeluruh in Buku Ajar Ilmu Penyakit Dalam Jilid I. Edisi V. Jakarta: Interna Publishing : 2009

14. Liesegang TJ. Conjunctiva in Textbook of Ophtalmology Edisi I. Amerika Serikat: William \& Wilkins: 1997

15. Ramesh S, Ramakrishnan R, Bharati MJ, Amutan M, Viswanathan S. Prevalance of Bacterial Pathogens causing ocular infections in South India, 2010. Indian Journal of Pathology and Microbiology diakses tanggal 28 Januari 2014 melalui http://imsear.hellis.org/handle/12345678 9/141663

16. Gevallos V, Whitcher JP, Melese M, Alemayabu W, Yi E, Chidambaram JD et al. Association of Conjunctival Bacterial Infection and Female Sex in Cicratical Trachoma, 2012. The Association for Research in Vision and 
Ophatalmology diakses tanggal 28 Januari $2014 \quad$ melalui http://www.iovs.org/content/53/9/5208.f ull

17. Tauber S, Cupp G, Garber R, Bartell J, Vohra F, Stroman D. Microbiological Effiacy of a New Ophtalmic Formulation of Moxifloxacin Dosed Twice-Daily for Bacterial Conjunctivitis, 2011. Springel diakses tanggal 28 Januari 2014 melalui http://link.springer.com/article/10.1007/s 12325-011-0037-x\#page-1

18. Dias C, Goncalves M, Joao A. Epidemiological Study of HospitalAcquired Bacterial Conjunctivitis in A Level III Neonatal Unit. 2013. Hindawi Publishing Corporation diakses tanggal 28 Januari 2014 melalui http://www.hindawi.com/journals/tswj/2 013/163582/abs/

19. Warsa UC, Josodiwondo S. Kokus gram positif, kokus gram negatif, chlamidya in Staf pengajar FKUI, editors. Buku Ajar Mikrobiologi Kedokteran. Edisi revisi. Jakarta;Binarupa Aksara; 1994

20. Epling J. Clinical Evidence Bacterial Conjunctivitis. 2009. BMJ Publishing Group. 2010. Diakses tanggal 28 Januari 2014 melalui http://www.ncbi.nlm.nih.gov/pmc/article s/PMC2907624/

21. Everts RJ, Barnett T, Lahood BR. The Utility of Routine Conjunctival Swabs in Management of Conjunctivitis. The New Zealand Medical Journal. 2011. Diakses tanggal 28 Januari 2014 melalui www.researchgate.net/publication/51034 507_CPR_for_all_Ethical_and_medicole gal_considerations/file/79e4150b9627f3 b8d7.pdf\#page $=64$

22. Harvey RA, Champe PC, Fischer BD. Lippincott's Illustrated Reviews: Microbiology Edisi 2. New Jersey: Lippincott Williams \& Wilkins : 2007 